\title{
Floristic survey of ornamental plants used in Dom Delgado University City at the Universidade Federal do Maranhão, São Luís, Maranhão State, Brazil ${ }^{(1)}$
}

\author{
LUANN BRENDO DA SILVA COSTA ${ }^{\left(2^{*}\right)}$, CAMILA DOS SANTOS PIRES(2), JÉSSICA SOUSA DOS ANJOS(2), \\ BRUNA EMANUELE FREIRE CORREIA(3), EDUARDO BEZERRA DE ALMEIDA JR.(4)
}

\begin{abstract}
The objective of this study is to list the flora used in ornamentation, afforestation and landscaping in the common areas of the Dom Delgado Campus (São Luís) at the Universidade Federal do Maranhão (2³2’20.7’S 44¹6'58.4”W), where this study was carried out. The collection took place through exploratory walks, including individual specimens planted there and those that were kept during the architectonical development of the University. Identification was obtained using analytical keys, specialized literature and the comparison with material previously identified in the Herbarium of Maranhão (MAR) where the exsiccates produced in the present study were deposited. 70 species, 56 genres and 29 families were found. Fabaceae (with 10 species), Apocynaceae (with nine spp.); Malvaceae and Rubiaceae (six spp.); Arecaceae (four spp.); Araceae, Bignoniaceae and Heliconiaceae with three species each were the most representative families in terms of the number of species. Among the total number of species identified, it was noted that there was no great difference in the quantity of native Brazilian species (38\%), when compared to exotic species (34\%); the remaining species were classified as cultivated (17\%) and naturalized (11\%). In conclusion, it is clear that the afforestation/ landscaping of the Dom Delgado Campus, follows a method of randomization in relation to the planting of the species used. Key words: Landscaping, native plants, campus, urban afforestation.
\end{abstract}

\section{RESUMO}

Levantamento florístico das plantas ornamentais utilizadas na Cidade Universitária Dom Delgado da Universidade Federal do Maranhão, São Luís, Maranhão, Brasil

O presente estudo tem como objetivo listar a flora utilizada na ornamentação, arborização e paisagismo das áreas comuns da Cidade Universitária Dom Delgado (campus São Luís) (2³2’20.7’'S 44¹6’58.4”W) da Universidade Federal do Maranhão. As coletas ocorreram por meio de caminhadas exploratórias, sendo coletados os indivíduos plantados e aqueles que no decorrer do desenvolvimento arquitetônico da Universidade foram mantidos. As identificações foram realizadas com auxílio de chaves analíticas, literatura especializada e por meio de comparação com material já identificado no Herbário do Maranhão (MAR) onde as exsicatas produzidas no presente estudo foram depositadas. Foram encontradas 70 espécies, 56 gêneros e 29 famílias. Fabaceae (com 10 espécies), Apocynaceae (com nove spp.); Malvaceae e Rubiaceae (seis spp.); Arecaceae (quatro spp.); Araceae, Bignoniaceae e Heliconiaceae com três espécies cada foram as famílias mais representativas em número de espécies. Do total de espécies identificadas, percebe-se que não há uma grande diferença na quantidade de nativas do Brasil (38\%), quando comparadas às exóticas (34\%); as demais foram classificadas como cultivadas (17\%) e naturalizadas (11\%). Por fim, fica evidenciado que a arborização/paisagismo da Cidade Universitária Dom Delgado, segue uma linha de aleatorização quanto ao plantio das espécies usadas.

Palavras-chave: Paisagismo, plantas nativas, campus, arborização urbana.

\section{INTRODUCTION}

Vegetation, with its ecological, economic and social functions, can play an important role in the life of urban populations. However, much of the plant community is subject to processes of landscape cleanup and environmental destruction. In this sense, a degradation of the natural landscapes is assuming unsustainable proportions, in relation to the loss of the native vegetation and the quality of the ecosystems before the increase of the number of cultivated and exotic plants (PAIVA et al., 2004).
However, plants grown in a city, both for ornamentation and afforestation, bring benefits ranging from a reduction of the islands of heat (LOMBARDO, 1985), to the increase of human well-being (GRAHN and STIGSDOTTER, 2010), also offering a support for housing, rest and nesting of urban fauna (MENEZES, 2004). Nowadays, an association between an afforestation / urban landscape and a quality of life of its inhabitants is undeniable (MILANO, 1995). In this context, ornamental plants are those that attract attention and arouse interests by their aesthetic characteristics such as color, leaf form and flowers, phenological aspects,

DOI: http://dx.doi.org/10.14295/oh.v23i4.1129

(1) Received in 02/11/2017 and accepted in 15/12/2017

(2) Universidade Federal do Maranhão (UFMA), Ciências Biológicas, Departamento de Biologia, São Luís - MA, Brasil.

(3) Universidade Federal do Maranhão (UFMA), Programa de Pós-Graduação em Biodiversidade e Conservação (PPGBC), São Luís - MA, Brasil.

(4) Universidade Federal do Maranhão, Departamento de Biologia, São Luís - MA, Brasil. *Autor correspondente: luanncostaslz@gmail.com.

Licensed by CC BY 4.0 
projected shadow, the swing caused by the wind and still by the visual structure formed with the plants nearby (SILVA, 2009). Trees may also be considered ornamental species, when they are planted to promote the beautification of the environment, adjusting to the free spaces, establishing a man-nature contact (SILVA, 2009).

In Brazil, plants that are used for ornamentation in landscaped environments are generally exotic and with little known phenology, whose planting has become exclusively due to unknowledge of the species (LORENZI and SOUZA, 2001). While they serve to enhance a scenic beauty of urban environments, these plants can pose problems when choices and plantings are inadequately. In most cases, the plants are selected only by analyzing their aesthetic traits, not considering important characteristics such as location of origin (HEIDEN et al., 2006), stem shape, crown shape, propagation velocity and growth (ZILLER, 2006). In this way, the practice of improving the scenic landscape requires knowledge of botany, ecology, regional climatic variations and architectural styles, as well as the study of plastic compatibilities for the balance of forms and colors (MARX and TABACOW, 2004).

In the urban arborization, are inserted the spaces of the Universities that are peculiar for the capacity to produce science and human resources, being able to become a space for floristic projects that consider the different aspects in the use of vegetal species, being these either native or exotic (EISENLOHR et al., 2008). This potential is evidenced by the floristic records developed by Paiva et al. (2004), Kurihara et al. (2005), Castro et al. (2011), Brianezi et al. (2013), in different Universities of Brazil.

Thus, the purpose of this study is to list the flora used in ornamentation, afforestation and landscaping in the common areas of Dom Delgado University City at the Universidade Federal do Maranhão.

\section{MATERIAL AND METHODS}

The collections of the species were carried out in the flowerbed, parking lots, main and secondary roads, gardens, interior and between the open areas of the buildings (Figure 1) of Dom Delgado University City (2³2’20.7 “S $44^{\circ} 16$ '58.4" W) at the Universidade Federal do Maranhão - UFMA (Figure 2), located in the municipality of São Luís, whose area has about $0.969 \mathrm{~km}^{2}$. The region has Aw type climate (KÖPPEN, 1948), tropical rainy, with predominance of rainfall in the months of January to June.

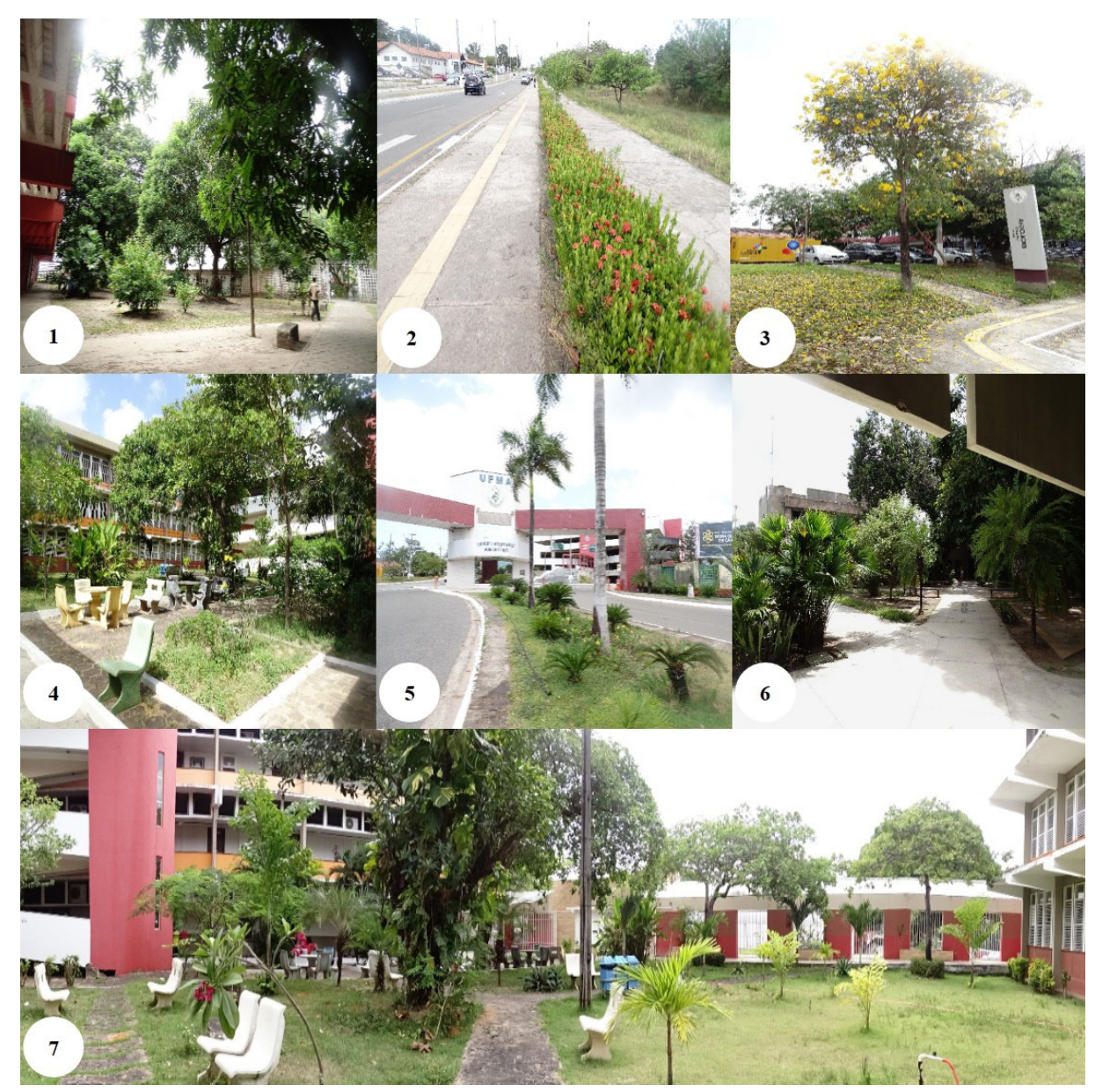

Figure 1. Collection areas in Dom Delgado University City - UFMA. (1= Rectory Building, 2 = Central campus, $3=$ Entrance to the Biological Sciences building, 4 = Exact Sciences and Technology building square, $5=$ Main University entrance, 6 = Rectory square, 7 = Square of the Social Sciences building). 
The study was developed from August 2016 to August 2017 by means of exploratory walks, collecting the individuals planted and those who were kept to shade and / or beautify the campus along the architectural development of the University. All specimens in the reproductive stage were collected, photographed and herborized according to the usual botanical methodologies (MORI et al., 1989; PEIXOTO and MAIA, 2013).
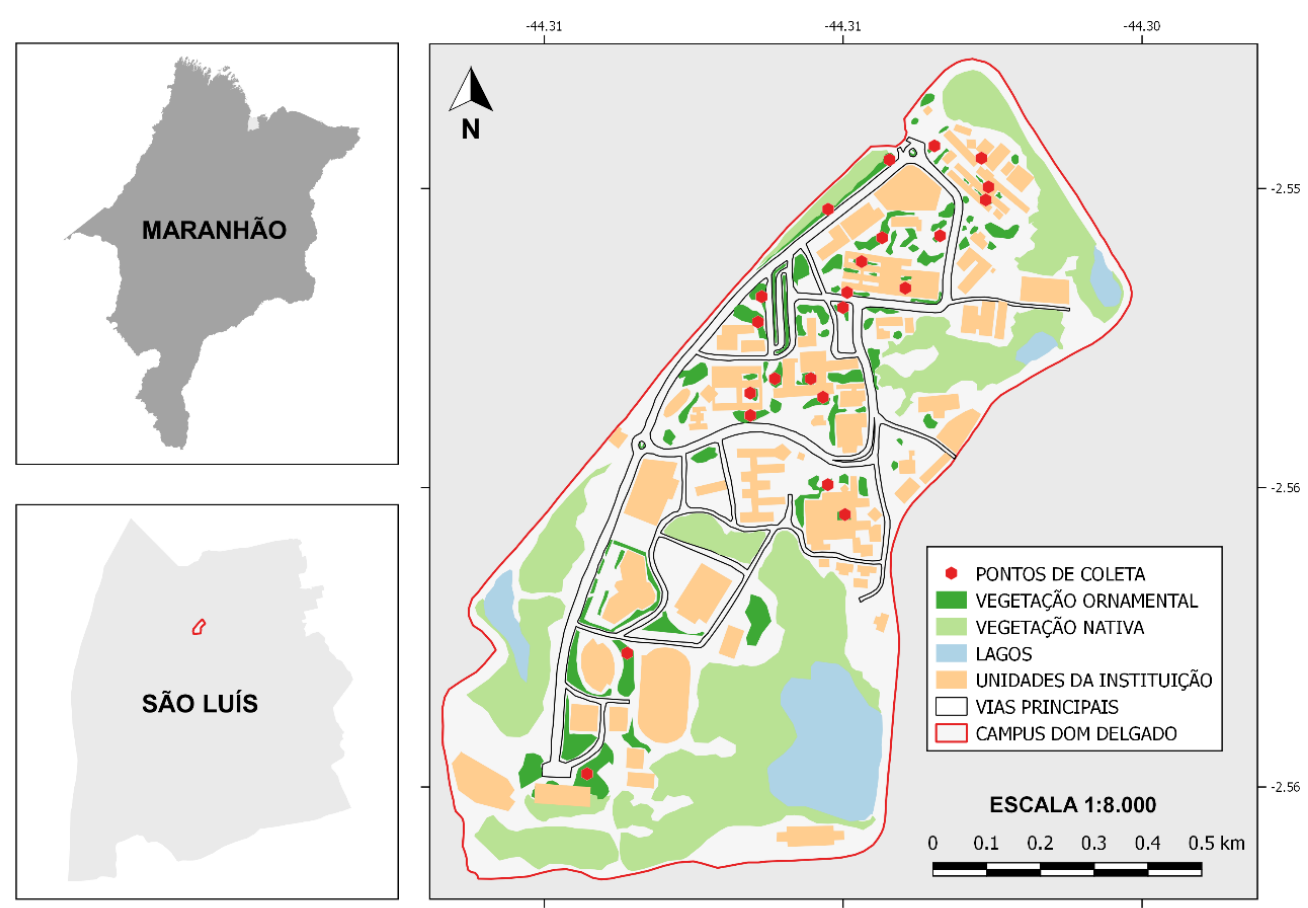

SISTEMA DE COORDENADAS SIRGAS 2000, EPSG: 4674; FONTE DE DADOS: IBGE (2017) E GOOGLE MAPS (2017); ELABORAÇÃO: DIAS, K. N. L., 2017.

Figure 2. Location of Dom Delgado University City at the Universidade Federal do Maranhão - UFMA, São Luís, Maranhão, Brazil.

Identifications were carried out with the help of analytical keys, specialized literature and by means of a comparison with material already identified in the Herbarium of Maranhão (MAR), Department of Biology, Universidade Federal do Maranhão (ALMEIDA JR. et al., 2015). The exsiccates produced in the present study were deposited in the Herbarium MAR.

The names of the species and their respective authors were verified in APG IV (2016); in the Tropicos databases (http://www.tropicos.org/), The Plant List (http://www. theplantlist. org/), Reflora (http://reflora.jbrj.gov.br/), Flora of Brazil (http://floradobrasil.jbrj.gov.br/). The studies of Lorenzi and Souza (2001), Delprete (2003) and Lorenzi (2013) that were consulted to identify cultivated plants. Where possible, the origin, habit, endemism and vernacular names associated with the species were also investigated.

\section{RESULTS AND DISCUSSION}

A total of 67 species were found, distributed in 57 genera belonging to 29 families (Table 1). Of the total species, two species are gymnosperms: Araucaria columnaris (J.R. Forst.) Hook. (Pinheiro-de-natal) and Cycas revoluta Thunb. (Sagu-de-jardim). It should be noted that Araucaria columnaris was also registered at the Universidade Federal de Viçosa, Minas Gerais (BRIANEZI et al., 2013). A. columnaris is used for ornamentation by resembling a pine tree, up to $60 \mathrm{~m}$ in height, the cream-colored wood (LORENZI, 2003). The $C$. revoluta is widely used in ornamentation due to its palm-like features, it has slow growth, but throughout its growth it is endowed with a crown of very ornamental leaves (LORENZI, 2013). 
Table 1. List of plants used in afforestation / landscaping of Dom Delgado University City at the Universidade Federal do Maranhão $($ Nati $=$ native from Brazil, Cult $=$ Cultivated, Exot $=$ Exotic, Natu $=$ Naturalized, Herb $=$ Herbaceous, Arbo $=$ Arboreal, Arbu $=$ Shrub, Palm $=$ Palm, Arbu $/$ Arbo $=$ Shrub/tree, Lian $=$ Liana $)$.

\begin{tabular}{|c|c|c|c|c|}
\hline Família/Espécie & Origem & Hábito & Nome popular. & Voucher \\
\hline \multicolumn{5}{|l|}{ Acanthaceae } \\
\hline Justicia calycina (Nees) V.A.W.Graham & Nati & Herb & Jacobínia-vermelha & MAR 9.624 \\
\hline \multicolumn{5}{|l|}{ Anacardiaceae } \\
\hline Anacardium occidentale L. & Nati & Arbo & Cajueiro & MAR 9.625 \\
\hline Mangifera indica $\mathrm{L}$. & Cult & Arbo & Mangueira & MAR 9.626 \\
\hline \multicolumn{5}{|l|}{ Apocynaceae } \\
\hline Allamanda blanchetii A.DC. & Nati & Arbu & Sete-patacas-roxa & MAR 9.627 \\
\hline Allamanda cathartica $\mathrm{L}$. & Nati & Arbu & Dedal-de-princesa & MAR 9.628 \\
\hline Catharanthus roseus (L.) Don & Cult & Herb & Maria-fedida & MAR 9.629 \\
\hline Nerium oleander L. & Cult & Arbo & Espirradeira & MAR 9.631 \\
\hline Plumeria pudica Schltdl. \& Cham. & Exot & Arbu/arbo & Jasmim do Caribe & MAR 9.632 \\
\hline Plumeria rubra L. & Exot & Arbu/arbo & Jasmim-manga & MAR 9.633 \\
\hline Tabernaemontana laeta Mart. & Nati & Arbu/arbo & $\begin{array}{l}\text { Lírio, jasmim, jasmim- } \\
\text { de-leite }\end{array}$ & MAR 9.634 \\
\hline Thevetia peruviana (Pers.) K.Schum. & Nati & Arbu/arbo & Chapéu de Napoleão & MAR 9.635 \\
\hline \multicolumn{5}{|l|}{ Araceae } \\
\hline Anthurium andraeanum Linden & Exot & Herb & Antúrio & MAR 9.636 \\
\hline Epipremnum pinnatum (L.) Engl. & Exot & Herb & Jibóia & MAR 9.637 \\
\hline Philodendron imbe Schott ex Endl. & Nati & Lian & Orelha de burro, jiboia & MAR 9.638 \\
\hline \multicolumn{5}{|l|}{ Araucariaceae } \\
\hline Araucaria columnaris (J.R. Forst.) Hook. & Exot & Arbo & Pinheiro de natal & MAR 9.639 \\
\hline \multicolumn{5}{|l|}{ Arecaceae } \\
\hline Adonidia merrillii (Becc.) Becc. & Exot & Palm & Palmeira-de-manila & MAR 9.640 \\
\hline Arenga caudata (Lour.) H.E. Moore & Nati & Palm & $\begin{array}{l}\text { Palmeirinha-rabo- de- } \\
\text { peixe }\end{array}$ & MAR 9.641 \\
\hline Cocos nucifera L. & Natu & Palm & Coco-verde, coco & MAR 9.642 \\
\hline Serenoa repens (W. Bartram) Small & Exot & Palm & Serenoa & MAR 9.643 \\
\hline Syagrus cocoides Mart. & Nati & Palm & Ariri & MAR 9.206 \\
\hline \multicolumn{5}{|l|}{ Asparagaceae } \\
\hline Agave americana $\mathrm{L}$. & Exot & Arbu & Pita, piteira & MAR 9.644 \\
\hline Asparagus densiflorus var. sprengeri Kunth & Exot & Herb & - & MAR 9.645 \\
\hline \multicolumn{5}{|l|}{ Bignoniaceae } \\
\hline Handroanthus impetiginosus (Mart. ex DC.) Mattos & Nati & Arbo & Ipê-roxo & MAR 9.646 \\
\hline $\begin{array}{l}\text { Tabebuia aurea (Silva Manso) Benth. \& Hook.f. ex } \\
\text { S.Moore }\end{array}$ & Nati & Arbo & Ipê-amarelo & MAR 9.647 \\
\hline Tecoma stans (L.) Juss. ex Kunth & Natu & Arbu & Ipê-de-jardim & MAR 9.648 \\
\hline \multicolumn{5}{|l|}{ Clusiaceae } \\
\hline Platonia insignis Mart. & Nati & Arbo & Bacuri & MAR 9.649 \\
\hline \multicolumn{5}{|l|}{ Combretaceae } \\
\hline Terminalia catappa L. & Natu & Arbo & Castanhola & MAR 9.650 \\
\hline \multicolumn{5}{|l|}{ Convolvulaceae } \\
\hline Ipomoea pes-caprae (L.) R.Br. & Nati & Herb & Salsa & MAR 9.651 \\
\hline \multicolumn{5}{|l|}{ Cycadaceae } \\
\hline Cycas revoluta Thunb. & Exot & Palm & Sagu-de-jardim & MAR 9.652 \\
\hline
\end{tabular}


Table 1. cont.

\begin{tabular}{|c|c|c|c|c|}
\hline \multicolumn{5}{|l|}{ Euphorbiaceae } \\
\hline Euphorbia tirucalli L. & Exot & Arbu & $\begin{array}{c}\text { Espinho-de-Crisro, } \\
\text { Avelós }\end{array}$ & MAR 9.653 \\
\hline Pedilanthus tithymaloides (L.) Poit. & Nati & Arbu & $\begin{array}{l}\text { Sapatinho-do-diabo, } \\
\text { dois-irmãos }\end{array}$ & MAR 9.654 \\
\hline \multicolumn{5}{|l|}{ Fabaceae } \\
\hline Acacia mangium Willd. & Exot & Arbo & Acácia & MAR 9.655 \\
\hline Adenanthera pavonina $\mathrm{L}$. & Exot & Arbo & Carolina & MAR 9.656 \\
\hline Andira sp. & Nati & Arbo & - & MAR 9.657 \\
\hline Arachis pintoi Krapov. \& W.C.Greg. & Nati & Herb & $\begin{array}{l}\text { Amendoinzinho, capim- } \\
\text { amendoim }\end{array}$ & MAR 9.658 \\
\hline Calliandra brevipes Benth. & Nati & Arbu & Esponjinha & MAR 9.659 \\
\hline Centrolobium tomentosum Guillem. ex Benth. & Nati & Arbo & Araribá & MAR 9.660 \\
\hline Delonix regia (Bojer ex Hook.) Raf. & Cult & Arbo & Flamboyant & MAR 9.661 \\
\hline Senna polyphylla (Jacq.) H.S.Irwin \& Barneby & Nati & Arbu/arbo & Cássia-baiana & MAR 9.662 \\
\hline Senna sp. & Nati & Arbo & - & MAR 9.663 \\
\hline Tamarindus indica $\mathrm{L}$. & Cult & Arbo & Tamarindo & MAR 9.664 \\
\hline \multicolumn{5}{|l|}{ Garryaceae } \\
\hline Aucuba japonica Thunb. & Exot & Arbu & Louro-do-Japão & MAR 9.665 \\
\hline \multicolumn{5}{|l|}{ Heliconiaceae } \\
\hline Heliconia acuminata L.C.Rich. & Nati & Herb & Heliconia & MAR 9.666 \\
\hline Heliconia bihai $\mathrm{L}$. & Exot & Herb & Caetê vermelho & MAR 9.667 \\
\hline Heliconia densiflora subsp. angustifolia L.Andersson & Nati & Herb & Caeté-fino & MAR 9.668 \\
\hline \multicolumn{5}{|l|}{ Lamiaceae } \\
\hline Gmelina arborea Roxb. ex Sm. & Exot & Arbo & Guemelina & MAR 9.669 \\
\hline \multicolumn{5}{|l|}{ Malpighiaceae } \\
\hline Byrsonima crassifolia (L.) Kunth & Nati & Arbo & Murici & MAR 9.670 \\
\hline \multicolumn{5}{|l|}{ Malvaceae } \\
\hline Hibiscus rosa-sinensis $\mathrm{L}$. & Exot & Arbu & Papoula & MAR 9.671 \\
\hline Hibiscus sabdariffa L. & Exot & Arbu & $\begin{array}{l}\text { Vinagreira, caruru- } \\
\text { azedo }\end{array}$ & MAR 9.673 \\
\hline Hibiscus schizopetalus (Boulger) Hook. f. & Exot & Arbu & Hibisco-crespo & MAR 9.674 \\
\hline Pachira aquatica Aubl. & Nati & Arbo & Falso cacau & MAR 9.675 \\
\hline Sterculia striata A.St.-Hil. \& Naudin & Nati & Arbo & Chichá & MAR 9.676 \\
\hline \multicolumn{5}{|l|}{ Moraceae } \\
\hline Ficus benjamina $\mathrm{L}$. & Natu & Arbu/arbo & Ficus & MAR 9.677 \\
\hline \multicolumn{5}{|l|}{ Myrtaceae } \\
\hline Psidium guajava L. & Natu & Arbo & Goiabeira & MAR 9.678 \\
\hline Syzygium jambos (L.) Alston & Natu & Arbo & Jambo, jambeiro & MAR 9.679 \\
\hline \multicolumn{5}{|l|}{ Nyctaginaceae } \\
\hline Bougainvillea spectabilis Willd. & Nati & Arbo & $\begin{array}{l}\text { Três Marias rosa, } \\
\text { vermelha e amarela }\end{array}$ & MAR 9.680 \\
\hline \multicolumn{5}{|l|}{ Oxalidaceae } \\
\hline Averrhoa bilimbi L. & Cult & Arbo & Limãozinho & MAR 9.681 \\
\hline \multicolumn{5}{|l|}{ Plantaginaceae } \\
\hline Russelia equisetiformis Schltdl. \& Cham. & Cult & Arbu & Flor-de-coral & MAR 9.682 \\
\hline \multicolumn{5}{|l|}{ Rosaceae } \\
\hline Rosa spinosissima $\mathrm{L}$. & Exot & Arbu & Roseira, rosa & MAR 9.683 \\
\hline
\end{tabular}


Table 1. cont.

\begin{tabular}{|c|c|c|c|c|}
\hline \multicolumn{5}{|l|}{ Rubiaceae } \\
\hline Ixora chinensis Lam. & Cult & Arbu & Ixora coral & MAR 9.684 \\
\hline Ixora coccinea $\mathrm{L}$. & Cult & Arbu & $\begin{array}{c}\text { Alfinete vermelho, } \\
\text { amarelo }\end{array}$ & MAR 9.685 \\
\hline Ixora coccinea var. lutea (Hutch.) Corner & Exot & Arbu & Alfinete amarela, creme & MAR 9.687 \\
\hline Ixora macrothyrsa Teijsm. \& Binn. & Cult & Arbu & Ixora-rei & MAR 9.689 \\
\hline \multicolumn{5}{|l|}{ Rutaceae } \\
\hline Murraya paniculata (L.) Jack & Exot & Arbo & Murta-de-cheiro & MAR 9.690 \\
\hline \multicolumn{5}{|l|}{ Verbenaceae } \\
\hline Duranta erecta $\mathrm{L}$. & Natu & Arbu & Pingo-de-ouro & MAR 9.691 \\
\hline Petrea volubilis L. & Nati & Arbu/arbo & Flor-de-são-miguel & MAR 9.692 \\
\hline \multicolumn{5}{|l|}{ Vitaceae } \\
\hline Leea rubra Blume ex Spreng. & Exot & Arbu/arbo & Léia-vermelha & MAR 9.692 \\
\hline
\end{tabular}

Regarding the habit, 24 tree species were found, totaling $36 \%$; 18 shrub species $(27 \%) ; 10$ herbaceous species $(15 \%)$; eight shrub/tree $(12 \%)$; six species of palm (9\%) and one liana (1\%) (Table 1).

The most representative families in number of species were Fabaceae with 10 species, Apocynaceae (eight spp.); Arecaceae and Malvaceae (five spp., each); Rubiaceae (four spp.); Araceae, Bignoniaceae and Heliconiaceae with three species, each. The greater representativeness of the families Fabaceae and Apocynaceae was also observed in the works developed by Kurihara et al. (2005) at the Universidade de Brasília; Eisenlohr et al. (2008) and Brianezi et al. (2013) both at the Universidade Federal de Viçosa.

There was a predominance of two families: Fabaceae, one of the largest families of angiosperms with cosmopolitan distribution and one of the main economically. The species of this family are always used in ornamentation and urban afforestation in Brazil, besides having species that produce quality wood (SOUZA and LORENZI, 2005). The Apocynaceae family also stands out for having pantropical distribution. Many species of this family are cultivated as ornamental, but several are toxic to humans and, for this reason, are not totally appropriate for cultivation in certain areas (SOUZA and LORENZI, 2005). Although toxic, species are used as ornamental. Therefore some care must be taken with the choice of spaces where these plants are placed in order to avoid direct contact with the population.

It is worth noting the presence of several plants that have toxic effects, such as Allamanda cathartica (dedalde-princesa), Catharanthus roseus (maria-fedida), Delonix regia (flamboyant), Euphorbia tirucalli (espinhode-cristo), Ficus benjamina (ficos), Nerium oleander (espirradeira), Pedilanthus tithymaloides (sapatinhodo-diabo), Philodendron imbe (orelha-de-burro, jiboia), Plumeria rubra (jasmim-manga) and Thevetia peruviana (chapéu-de-napoleão) (FARIAS, et al., 2003; MATOS et al., 2011). According to Matos et al. (2011), care must be taken when using such species for ornamentation in urban environments because they contain toxins that are harmful to human health.
Nascimento et al. (2015) carried out a preliminary survey at University Center Itajubá, MG, and also listed some plants used for ornamentation, but which contain toxic substances. That, according to Cavalcanti et al. (2004), can representing a danger to the local ecosystems, being able to occupy the niche of the native species (DISLICH et al., 2001).

From the total number of species identified, there is no significant difference between the number of exotic species (34\%) and native species in Brazil (40\%). Cultures (15\%) and naturalized (11\%), although used, had little representativeness for the present study. Similar results were found by Carvalho et al. (2007) at the Universidade Federal da Bahia; Potascheff et al. (2012) at the Universidade Estadual Paulista Júlio de Mesquita and by Brianezi et al. (2013) at the Universidade Federal de Viçosa.

In the study by Eisenlohr et al. (2008), also in the Universidade Federal de Viçosa, the predominance of exotic species was higher than the native ones, showing that although there is a greater number of native species in many works, the choice for exotic plants still stands out, being a factor that must be considered in urban afforestation and landscaping projects. It is necessary to give preference to the autóctones species, that is, those that are native to the natural ecosystems of each region where the city is located, as these would benefit urban ecosystems (CASTRO et al., 2011).

At UFMA, the Allamanda blanchetii (sete-patacasroxa), Arachis pintoi (amendoinzinho, capim-amendoim), Bougainvillea spectabilis (três-marias), Centrolobium tomentosum (araribá), Philodendron imbe (orelha-de-burro, jiboia), Sterculia striata (chichá), Syagrus cocoides (ariri) e Tabernaemontana laeta (lírio, jasmim, jasmim-de-leite), that are typical of the Caatinga, Cerrado, Atlantic Forest and Amazon, were found, showing the importance of these species to the area of the present study because they are plants adapted to local conditions, especially those from Amazon. Thus, it is understood that such species should have priority in a landscaping plan in urban environments.

It is evidenced that the arborization/landscaping of Dom Delgado University City, apparently, does not follow a planned landscape line due to the lack of organization 
of the aesthetic characters in relation to the plants chosen (Figure 3), being perceived the "randomization" of the planting of the species used. Thus, the present study may serve as a basis for a management plan for more consistent ornamentation, following a clear, efficient and didactic proposal (LEAL et al., 2009), and in the future replace the species considered inadequate for planting in Maranhão.



Figure 3. Plants used for ornamentation Dom Delgado University City - UFMA. (1 = Philodendron imbe Schott ex Endl., 2 = Sterculia striata A.St.-Hil. \& Naudin, 3 = Petrea volubilis L., $4=$ Nerium oleander L., $5=$ Delonix regia (Bojer ex Hook.) Raf., 6 = Adenanthera pavonina L., 7 =Ixora coccinea L., 8 = Agave americana L., $9=$ Hibiscus rosa-sinensis L.).

\section{CONCLUSIONS}

It can be concluded that the data of the present study could contribute in the elaboration of a more efficient afforestation and ornamentation plan to contribute to the "beautification" of the common areas Dom Delgado University City, giving priority to native species in the face of scenic beauty. In addition, it can help in future works that aim at the use of plants more suitable for the region, prioritizing the native species to the detriment of the exotic species; investing in the reproduction of the native species to replace or isolate of the exotic species.

\section{CONTRIBUTIONS OF AUTHORS}

LBSC: Bibliographic review, data collection, species identification, data analysis and interpretation, manuscript preparation. CSP: Bibliographic review, data collection, species identification, data analysis and interpretation, manuscript preparation and technical activities. JSA: Bibliographic review, data collection, species identification, data analysis and interpretation, manuscript preparation and technical activities. BEFC: Data collection, species identification, data analysis and interpretation, manuscript review. EBAJ: Conception of the study, critical review of the results, approval of the final version of the manuscript.

\section{ACKNOWLEDGMENT}

We thank the Universidade Federal do Maranhão for making space available for the development of this study. To the Laboratório de Estudos Botânicos (LEB) for the concession of the equipment and physical space. To the Herbarium MAR by the exsiccate data. PROAES/UFMA for the first author's scholarship.

\section{REFERENCES}

ALMEIDA JR, E.B. Herbário do Maranhão, Maranhão (MAR). Unisanta BioScience, v.4, n.6, p.129-132, 2015.

BRIANEZI, D.; JACOVINE, L.A.G.; GONÇALVES, W.; ROCHA, S.J.S.S. Evaluation of afforestation on the main Campus of the Universidade Federal de Viçosa, Minas Gerais state, Brazil, REVSBAU, v.8, n.4, p.85-100, 2013. 
CARVALHO, G.M.; ROQUE, N.; GUEDES, M.L.S. Levantamento das espécies arbóreas da Universidade Federal da Bahia, Salvador, Bahia. Sitientibus série Ciências Biológicas, v.7, n.4, p.377-387, 2007.

CASTRO, A.S.F.; MORO, M.F.; ROCHA, F.C.L. Plantas dos espaços livres da Reitoria da Universidade de Fortaleza (UNIFOR), Ceará, Brasil. Revista Brasileira de Biociências, v.9, n.1, 2011.

CAVALCANTI, L.F.C.; DANTAS, I.C.; SILVA, G.M.C.; COSTA, L.L.; BARROS, M.J.B.; LIRA, R.S. Identificação dos vegetais destinados a ornamentação de praças, parques e creches em Campina Grande, PB. Revista de Biologia e Ciências da Terra, v.4, n.1, 2004.

DELPRETE, P.G. Revision and typification of some species of Ixora (Rubiaceae) from central and southern Brazil. Contributions to Botany, v.20, n.4, p.1471-1480, 2003.

DISLICH, R.; CERSÓSIMO, L.; MANTOVANI, W. Análise da estrutura de fragmentos florestais no Planalto Paulistano-SP. Revista Brasileira de Botânica, v.24, n.3, p.321-332, 2001.

EISENLOHR, P.V.; CARVALHO-OKANO, R.M.; VIEIRA, M.F.; LEONE, F.R.; STRINGHETA, A.C.O. Flora fanerogâmica do campus da Universidade Federal de Viçosa, Viçosa, Minas Gerais. Revista Ceres, v.55, n.4, 2008 .

FARIAS, M.L.F.; DANTAS, I.C.; LIRA, R.S.; OLIVEIRA, J.M.C.; ALBUQUERQUE, H.N.; ALBUQUERQUE, I.C.S. Identificação dos vegetais tóxicos da cidade de Campina Grande-PB. Revista de Biologia e Ciências da Terra, v.3, n.1, 2003.

GRAHN, P.; STIGSDOTTER, U.K. The relation between perceived sensory dimensions of urban green space and stress restoration. Landscape and urban planning, v.94, n.3, p.264-275, 2010.

HEIDEN, G.; BARBIERI, R.L.; STUMPF, E.R.T. Considerações sobre o uso de plantas ornamentais nativas. Ornamental Horticulture, v.12, n.1, 2006.

KÖPPEN, W. Climatologia. México. Fundo de Cultura Econômica, 1948.

KURIHARA, D.L.; IMAÑA-ENCINAS, J.; PAULA, J.E. Levantamento da arborização do campus da Universidade de Brasília. Revista Cerne, v.11, n.2, p.127-136, 2005.

LEAL, L.; PEDROSA-MACEDO, J.H.; BIONDI, D. Censo da arborização do campus iii-centro politécnico da universidade federal do Paraná. Scientia Agraria, v.10, n.6, p.443-453, 2009.
LOMBARDO, M.A. A ilha de calor nas metrópoles: o exemplo de São Paulo. Editora Hucitec, Sao Paulo, Brasil, 1985.

LORENZI, H. Plantas para jardim no Brasil: herbáceas, arbustivas e trepadeiras. Nova Odessa: Instituto Plantarum, 2013. 1120p.

LORENZI, H. Árvores exóticas no Brasil: madeireiras, ornamentais e aromáticas. Nova Odessa: Institituto Plantarum, 2003. 368p.

LORENZI, H.; SOUZA, H.M. Plantas ornamentais do Brasil: arbustivas, herbáceas e trepadeiras. Nova Odessa: Instituto Plantarum, 2001. 1088p. vol.3.

MARX, R.; TABACOW, J. Arte \& paisagem: conferências escolhidas. Studio Nobel, 2004.

MATOS, F.J.A.; LORENZI, H.; SANTOS, L.F.L.; MATOS, M.E.O.; SILVA, M.G.V.; SOUSA, M.P. Plantas Tóxicas: estudo de fitotoxicologia química de plantas daninhas. Nova Odessa: Instituto Plantarum de Estudos da Flora, 2011. 270p. vol.1.

MENEZES, M.O.T. The use of date palms (Phoenix sp.) as resting and sleeping sites by Callithrix jacchus in Northeastern Brazil. Neotrop Primates, v.12, p.53-55, 2004.

MILANO, M.S. Planejamento da arborização urbana: relações entre áreas e ruas arborizadas. Curitiba: Universidade Livre Do Meio Ambiente, 1995. 71p. v.3.

MORI, L.A.; SILVA, L.A.M.; LISBOA, G.; CORADIN, L. Manual de manejo do herbário fanerogâmico. Ihéus: Centro de pesquisa do Cacau, 1989. 42p. vol.1.

NASCIMENTO, A.V.B.; RENNÓ; C.S.M.; NUNES, G.A.; SIMÕES, R.S.; PASIN, L.A.A.P. Levantamento preliminar de plantas tóxicas do Centro Universitário de Itajubá-FEPI. Revista Científica da FEPI, v.8, n.2. 2015.

PAIVA, P.D.O.; LANDGRAF, P.R.C.; RODRIGUES, T.M.; PEDROSO, D.O.; FILHO, T.O.; GAVILANES, M.L.; PAIVA, R. Identification and characterization of the trees species of the central garden of the Universidade Federal of Lavras/MG. Ciência e Agrotecnologia, v.28, n.3, p.515-519, 2004.

PEIXOTO, A.L.; MAIA, L.C. Manual de Procedimentos para herbários. INCT-Herbário virtual para a Flora e os Fungos. Recife: Editora Universitária UFPE, 2013. 96p. vol.1.

POTASCHEFF, C.M.; LOMBARDI, J.A.; LORENZI, H. Angiospermas arbóreas e arbustivas do campus da Universidade Estadual Paulista Júlio de Mesquita, Rio Claro (SP). Bioikos, v.24, n.1, 2012. 
SILVA, L.C. Plantas ornamentais tóxicas presentes no shopping Riverside Walk em Teresina-PI. REVSBAU, v.4, n.3, p.69-85, 2009.

SOUZA, V.C.; LORENZI, H. Botânica Sistemática: guia ilustrado para identificação das famílias de angiospermas da flora brasileira, baseado em APGII. Nova Odessa: Instituto Plantarum, 2005. 640p. vol.1.
ZILLER, S.R. Espécies exóticas da flora invasoras em Unidades de Conservação. Unidades de conservação, p.34, 2006. 